\title{
Farmers' And Retailers' Knowledge Level Associated with Pesticide Distribution and Application in Horticultural Production Centers in Karo Regency, North Sumatera
}

\author{
Catur Hermanto ${ }^{1}$, Rasiska Tarigan ${ }^{1}$, Agustina E. Marpaung ${ }^{1}$ \& Rina. C.Hutabarat ${ }^{1}$ \\ ${ }^{1}$ Indonesian Vegetables Research Institute - Agricultural Research Development Agency \\ Jln Tangkuban Perahu No 517, Lembang, Bandung Barat 40391 \\ Corresponding author: mirasiskatarigan@ymail.com
}

\section{ARTICLE HISTORY \\ Received : 19 August 2019 \\ Revised : 14 September 2019 \\ Accepted : 5 October 2019}

\section{KEYWORDS}

Correlation;

Level of knowledge;

Retailers;

Farmers;

Karo District;

\begin{abstract}
The description of the agriculture success is inseparable from the level of knowledge of retailers and farmers on the effective use of pesticides in the field. This study aimed at evaluating the relationship between the level of knowledge of retailers and farmers on the distribution and use of pesticides in vegetable production centers in Karo Regency. The research was Berastagi Experimental Farm from August to September 2016. The research method used in the survey was a cross-sectional study approach. The selection of districts was done purposively based on the highest number of retailers, the largest horticultural planting area, and the number of vegetable farmers per district. The number of research samples was 10 respondents per district. To analyze the relationship between variables, we used Spearman's range correction coefficient calculation and validity test using SPSS correlation 17 . The results exhibited that the level of knowledge of retailers and farmers in Karo regency is low about the functions, codes, and formulations of all pesticides that have been distributed. The level of knowledge of vegetable farmers on the use of pesticides in Karo district is low, seen from the high level of use, increasing concentration of pesticides and high frequency of spraying, as well as mixing fungicides and insecticides 2 types of pesticides with different codes and active ingredients. The relationship of farmers' knowledge with their age, education and the length of farming experience significantly influenced the perception and attitude of using pesticides to control pest attacks in their lands of cultivation.
\end{abstract}

This is an open access article under the CC-BY-SA license.

\section{INTRODUCTION}

An increase in population correlated to the increase of demand for agricultural products, such as horticultural products every year. The farmers have been trying to put some efforts to fulfill their needs. Unfortunately, the farmers often experience failure due to pest and disease attack in their crops. To overcome this problem, the farmers have done everything to control pest and disease attack. One of them is by applying synthetic pesticides (Try et al, 2013). Agne et al. (1995) stated that the extensive use of synthetic pesticides in developing countries is due to the lack of information about pesticides and also farmers' unreadiness to be failed when harvesting. In the world of agriculture, it is undeniable that pesticides are inseparable from farmers and crops, which is its residues are hazardous for agricultural products. Generally, these residues exist when the pesticides are applied directly to the plants (Euis et al., 2016). Farmers considered the use of synthetic pesticides as the most effective way to control pests and disease attacks (Ameriana, 2008).

Karo Regency is known as one of the agricultural centers in North Sumatera. This place is considered as the producer of horticultural products such as vegetables and fruits. Most of Karo people rely on agricultural products for their sources of income. There is fluctuating productivity in the horticulture sector from 2012-2015, it is 42769.87 quintals/ha, 324.67 quintals/ha, 427.09 quintals/ha and 210.298 quintals/ha which caused fluctuation in product prices (BPS, 2016).

Agricultural products from Karo Regency are not only marketed in Sumatera Province but also they have been exported abroad, $80 \%$ of products are harvested for people of North Sumatera, and $20 \%$ are harvested for export as they contributed $60.46 \%$ of the products to the 
Gross Regional Domestic Product GRDP (BPS, 2015). Ita dan Syaad (2013) reported that horticultural products produced by farmers in Karo Regency had been marketed to Malaysia and Singapore in the early 1950s, and it has been succeeded since then. This is something promising and beneficial for the people of Karo as their export activity has increased the country's foreign exchange. However, export activity is decreased every year. The main obstacle is pest and disease attacks in the field.

The farmers in Karo apply about 10 tonnes of pesticides daily to their plantations, which is means they apply the pesticides intensively. It can be said that there is a possibility for them to be exposed by chemical residues. This excessive use of pesticides can cause environmental degradation and also toxic for humans (Wiji et al 2014; Zulfita, 2019).

The distribution and marketing of synthetic pesticides in Karo Regency were done by distributors, wholesalers, groceries, and retailers. It should be clear that these sellers need to explain how to use these pesticides properly in order to avoid pest and disease resistance and also high levels of pesticide residues. The research of Ameriana et al. (2006) revealed that the use of synthetic pesticides on tomato plants caused the residues to the products after harvest, even though the products have been washed, but this treatment was not effective because it is only reduced the inhibition value from $61,175 \%$ to $60.18 \%$ and reduced the inhibition value of fungicide from $70.64 \%$ to $50.28 \%$. The lower knowledge about these pesticides and less information about them affected the use of pesticides by farmers.

Regarding this phenomenon, we researched the correlation between farmers' and retailers' knowledge of the distribution and the use of pesticides in the Karo Regency.

\section{MATERIALS AND METHODS}

\subsection{Place and duration}

This research was conducted in Berastagi Experimental Farm in Tongkoh district, Karo Regency, from August to September 2016.

\subsection{The scope of the research}

The data were collected from retailers and farmers in four districts in Karo Regency. The location was Dolat Rayat District, Berastagi District, Namanteran District, and Kabanjahe District by using the respondent system.

This research used a survey method with a sectional study approach, the method which describes the temporary conditions, which only used during research with examining the causes of the uses of pesticides at that time (Catur et al., 2013; Maisura, 2019; Savitri, 2019). The selection of districts was done purposively based on the highest number of retailers, the largest vegetable planting area, and the number of vegetable plantations owned by farmers per district. Each district included ten respondents. Data collected by a) Interviewing the respondents using questionnaires that have a list about their identities such as age, gender, educational background, and also about how long they have run their business. The behavior of respondents (retailers) to the distribution of pesticides have been estimated by retailers' knowledge associated with the distribution of pesticides to farmers, b) Observation to the farmers' plantation to have information about their attitude in using pesticides to control pest and disease attacks and also their source of knowledge about the use of pesticides.

\subsection{Data analysis}

Chi-square $\left(\mathrm{X}^{2}\right)$ test has been assigned to reveal the relationship between age, educational background, and the time length of selling an experience to the distribution of pesticides, behavior and attitude of farmers to determine the correlation between them at each variable observed at probability level $5 \%$. Value of $\chi^{2}$ has been estimated using the formula: $\chi \mathbf{2}=\boldsymbol{\Sigma}(\mathbf{f o}-\mathbf{f e})^{2} / \mathbf{f e}$

Where:

$\chi^{2}=$ chi-square value,

fo $=$ observed frequency

$\mathrm{fe}=$ expected frequency

Expected frequencies were calculated using the formula: $\mathrm{Fe}=$ row total $\mathrm{x}$ column total /total of observation. If $\chi 2>\chi 2 \alpha$ with degree of freedom (df)=(c-1) $(r-1)$, reject $\mathrm{H}_{0}$ (null hypothesis) if these two factors are free at level $\alpha=5 \%$, if not, accept $H_{0}$ (null hypothesis) (Jacob Siegel \& Swanson, 1983).

\section{RESULTS AND DISCUSSION}

\subsection{Respondents characteristics}

The ten respondents selected were pesticide retailers and farmers from four different districts in Karo Regency. It is Dolat Rayat, Berastagi, Namanteran, and Kabanjahe. Respondent's characteristics obtained from the information collected: respondent's age, gender, educational background, selling experience and also their behavior in selling pesticides to consumers (Table 1). 
Table 1. The Mean Values of Characteristics of Respondents (Retailers) Based on Their Age, Sex, Educational Background, and Selling experiences

\section{Variables}

\begin{tabular}{|c|c|}
\hline Variables & $\begin{array}{l}\text { Measurement of effect } \\
\text { (\%) }\end{array}$ \\
\hline \multicolumn{2}{|l|}{ Retailers classification by gender } \\
\hline Male & $77.5 \%$ \\
\hline Female & $22.5 \%$ \\
\hline \multicolumn{2}{|l|}{ Retailers classification by group of age } \\
\hline 10 years old- 30 years old & - \\
\hline$>30$ years old -50 years old & $75 \%$ \\
\hline$>50$ years old- 70 years old & $25 \%$ \\
\hline \multicolumn{2}{|l|}{$>70$ years old } \\
\hline \multicolumn{2}{|c|}{ Retailers classification by educational background } \\
\hline Elementary school & $5 \%$ \\
\hline Junior high school & $12.5 \%$ \\
\hline Senior high school & $27.5 \%$ \\
\hline Diploma & $12.5 \%$ \\
\hline Bachelor's degree & $42.5 \%$ \\
\hline \multicolumn{2}{|c|}{ Retailers classification by time length of business } \\
\hline 1-5 years old & $15 \%$ \\
\hline$>5$ years old -10 years old & $32.5 \%$ \\
\hline$>10$ years old-15 years old & $17.5 \%$ \\
\hline$>15$ years old-20 years old & $20 \%$ \\
\hline$>20$ years old & $15 \%$ \\
\hline
\end{tabular}

Table 1 showed that male retailers were more dominant (77.5\%) compared to female retailers $(22.5 \%)$, and retailers aged 30-50 years old reached up to $75 \%$ with average age 40 years old. These results indicated that they were considered productive. Retailers with the group of age 15-64 considered productive human resources who can absorb and digest innovative information and technology in agriculture (Saut et al., 2014).

Education level is also affected someone's creativeness and ability to receive new innovative technology and spreading information, which definitely will affect the way farmers manage their agricultural farm. Retailers with university educational backgrounds reached up to $60 \%$ followed by senior high school $40 \%$. These retailers who graduated from the university have a better ability to absorb the information and smarter in technology and innovation. They have no difficulties in spreading information to farmers. Nonetheless, most of them have a degree in Economics, Law, and Agriculture. Absolutely this thing affects their ability to sell the products.

\subsection{The Distribution of Pesticides and Respondents' Behaviour associated with Pesticide Distribution to Farmers}

The key to success in selling pesticides is in line with the ability to sell the products which can solve farmers' problems. It can be proved from the way the retailers sell their products to farmers (Table 2). 
Table 2. The Mean Values of Variables Observed to Determine Pesticide Distribution System, Knowledge of Retailers in Selling Pesticides to Famers

\section{Variables}

Variables

(How many pesticides have you been sold?)

$>100$

$>50-100$

$0-50$

(The frequency of visits done by pesticide promoters to check product stock)

Often

Rare

Never

Are you selling pesticides that the formulation accepted by the Ministry of Agriculture?

Hazardous chemical compounds

Limited chemical compounds

Chemical compounds used as crop management

Chemical compounds used as synthetic

pesticides/metabolite/mineral/attractant/feromon/growth regulator

How long it takes for a retailer to sell a product?

$1-6$ months

6 months-1 year

$\geq 1$ year

Do retailers sell pesticides that fit the pesticide codes and farmer's problems?

Yes

Sometimes

No

Do retailers have knowledge about the working code required in each pesticide product they sell?

Yes they do

No, they do not

Do retailers know about the function and advantages of the pesticides they sell?

100 Yes

50:50

No

Do retailers know the hazardous formulation of pesticides classified by

WHO?

Yes

No

As a pesticide retailer, do you advise farmers not to use pesticides too often?
Measurement of effect

(\%)

$\begin{array}{ll}50 & \% \\ 25.78 & \% \\ 24.22 & \%\end{array}$

$10 \%$

$15 \%$

$50 \%$

$25 \%$

$50 \%$

$30 \%$

$20 \%$

$25 \%$

$35 \%$

$40 \%$

$17.5 \%$

$82.5 \%$

$\begin{array}{ll}52.5 & \% \\ 42.5 & \% \\ 5 & \%\end{array}$

$27.5 \%$

$72.5 \%$ 
Yes

No

Do you have ever returned pesticide products to distributors?)

Yes

No

Do you have ever received complaints from the buyer that the products they

bought that was not effective anymore to controlling pest/diseases in the

field)

Yes

No
$62.5 \%$

$37.5 \%$

$22.5 \%$

$77.5 \%$

$65 \%$

$35 \%$
Table 2 indicated that retailers had been sold 100 different pesticide products that contain similar chemical compounds. Promotors checked the products sold by retailers by visiting the retailers' shops. Data collected revealed that the $50 \%$ retailers were selling pesticides which its formulation is qualified and accepted by the Ministry of Agriculture, followed by 25\% retailers sold pesticides with chemical or synthetic compounds/ metabolite/mineral/attractant/feromon/growth regulator. The time length of selling was 0-6 months. The results illustrated that most of the retailers (40\%) sold pesticides that unfit the pesticide codes and farmers' problems. This condition indicated that good collaboration between distributors and retailers is needed in the marketing system, which involved the frequency of visits, socialization and product checking. Also, the collaboration with farmers is needed in order to let them know about the chemical properties and codes of pesticides established by the Ministry of Agriculture. The results also exhibited that $82.5 \%$ of retailers in Karo Regency did not know the codes required in pesticides they sell and $72.5 \%$ of them did not know about hazardous formulation in pesticides. This result gave information to us that most of the retailers had poor knowledge about pesticides, which contributed negatively to human's health (farmers and consumers). Pham et al. (2009) said that it could cause environmental degradation and increase the presence of secondary pests and also it will increase pest resistance.

\subsection{Farmers'Attitude in Using Pesticides in Karo Regency}

Farmers as individuals have distinguished characteristics that appear in carrying out their activities. Individual characters are a part of personalities that are inherent in themselves.

The results described that male farmers were more dominant (87.5\%) compared to female farmers $(12.5 \%)$ in 4 different districts observed in Karo Regency. It indicated that male farmers play a greater role in agriculture, specifically in land management and crop maintenance, while female farmers are responsible for planting and monitoring plant growth. From data collected, it showed that reproductive farmers ranged from 30-50 years old (mean values $77.5 \%$ ). It showed that Karo Regency has productive human resources. Productive farmers have more exceptional ability producing and working compared to unproductive ones so that it affects the production (output) and their income.

In those four districts, most farmers were graduated from senior high school, and the farmers with university educational background (Diploma and Bachelor's degree were at the lowest percentage. Low level of education influences their insight, knowledge and also their ability to mastering their work. Farmers with a higher level of education will be able to digest the information and understand quickly and rationally about innovative technology in agriculture, while farmers with a lower level of education also can absorb information quickly, but they cannot filter the information they get from friends or other retailers.

The low level of farmers' knowledge about pesticides is related to their behaviors and way of thinking in solving problems in the field. According to the research done by Nunung et al. (2011), people who work in agricultural sectors have a lower level of education compared to people working as a civil servant in agricultural sectors under governmental bodies. It affected the way they decided on the field. Luluk et al. (2008) reported that there are several factors which proved that there is a weak correlation between attitude and action of farmers, such as (1) Anxiety, where farmers are not ready to face failure in harvesting and always feel anxious about having no income from that failure, (2) Forecasting, where most of farmers have no ability to predict pest and disease attacks which triggered them to apply pesticides regularly, (3) Low awareness of farmers in implementing pest integrated management resulted from lack of continuous management and monitoring by agricultural extension officers; (4) Behavior Intention, where farmers have awareness implementing integrated pest management driven by cognitive aspect. However, this intention is strongly influenced by their surroundings, which sometimes inhibit them to work appropriately. 
Table 3. The Mean Values of Characteristics of Respondents (Horticultural Farmers) in Karo Regency Based on Their Group of Age,

Gender, Educational Background, Farming Experience, Types of Plants Grown and Planting Area

Variables

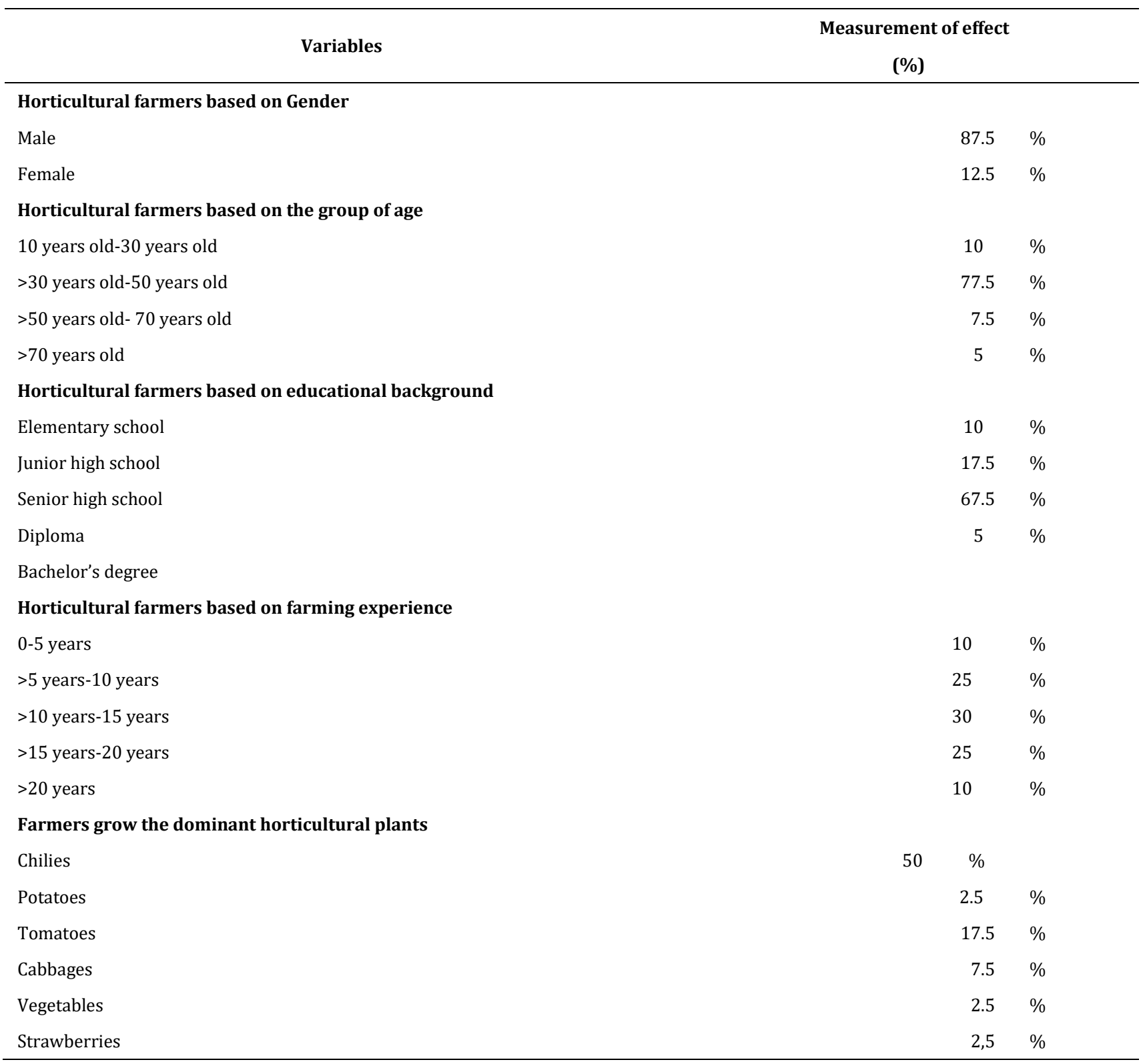

From their farming experiences, the time length varied from 10-15 years (30\%). It illustrated that the farmers were experienced enough and had adequate professionalism in agriculture. The longer a person's experience in a particular field, that person is considered as a person who has more knowledge about it. Asih (2009) suggested that experience in farming is a learning process that enables and eases us to adopt and implement technologies dynamically. A survey revealed that the farmers of Karo preferred to cultivate horticultural products, such as chilies (50\%), potatoes $(22.5 \%)$, and tomatoes $(17.5 \%)$. It showed that the farmers preferred to grow plants belong to one family (for instance, plants belong to family Solanaceae) for years. Unfortunately, this habit caused an unbreakable food chain to pests in the field.

\subsection{Perception of farmers in Karo Regency in using pesticides to control pests and diseases}

The farmers of Karo have the perception to control pests and diseases plants in the filed using pesticides. They have experienced many obstacles in growing their crops, which failed when harvesting. It is due to farmers do not know pests and diseases which attack their plants. There were $87.5 \%$ of farmers who do not know about it regarding the data collected. Besides, they (75\% of farmers) also apply chemical pesticides without evaluating the incidence of 
pest and disease attacks. Sadly, $47.5 \%$ of farmers decided to control the pests immediately using chemical pesticides even though the incidence pest level was only $1 / 16$ from a whole plant grown. This is happened due to farmers' lack of knowledge about pests and diseases. Lack of knowledge attributed to reckless actions, which most of farmers were convinced that high yields are only possible through using synthetic pesticides without considering the advantages of botanical or biological pesticides as a safer option to control pests and diseases. Gonzales et al. (2007) informed that chemical/ synthetic pesticide application had been farmer's first choice to control pests and disease because it is practice fast, and it increases the crop yields, which resulted in an increased profit for farmers. The high percentage of farmers using pesticides is inseparable from the dependence and traditions of farmers in cultivating crops from generation to generation (Lilis.,
2015).

The data showed that $52.5 \%$ of farmers of Karo did not know the adverse effects chemical pesticides cause and $50 \%$ of farmers applied pesticides twice a week, starting from 2-3 weeks after planting. It was surprising that most of the farmers $(80 \%)$ have mixed more than 2 different types of fungicides and insecticides at one time without distinguishing the type of formulation and work code from each pesticide, and they have considered that as an appropriate thing to do. Some farmers $(40 \%$ of farmers) have increased dose $1 / 2$ from the recommended dose. The results of Firman et al. (2010) revealed that knowledge, behavior and action of farmers in Tegal, Center Java in using inappropriate pesticides demonstrated a significant effect of chemical exposure to humans and the environment. The results were presented in Table 4.

Tabel 4. The Mean Values of Farmers' Perception and Behavior in Using Chemical Pesticides to Control Pests and Diseases

Variables

Measurement of effect

(\%)

What are the obstacles farmers often have in controlling pests and diseases?

Lack of knowledge about pests and diseases which attack the crops

$87.5 \%$,

They know pests and diseases which attack the crops

How do you control the pest and diseases that attack your plants?

Manually/mechanical/sanitation

Cultural control (application of plastic mulch, drainage upgrading)

$7.5 \%$

Application of biological/botanical pesticides

Application of chemical pesticides

$75 \%$

Other

When you use chemical pesticides, how often you apply them to plants to control

pests and diseases?

once a week

twice a week

three times a week

four times a week

once in 2 weeks

Other

Did you apply mixed pesticides or non-mixed pesticides?

I applied non-mixed pesticides with their had applicators

I applied 2-3 insecticides/fungicides alone at one time

I applied 4-5 insecticides/fungicides alone at one time

Mixing more than two different types of fungicides and insecticides at one time

Pesticide doses used by farmers

As required

Increased dose $1 / 4$ from the dose required 
Doubled the required dose

Others

Do farmers know about the codes when they buy pesticides?

Yes

No

Do farmers aware of the negative impact pesticides cause on the environment and human health?

Yes

No

Do farmers calculate the pest incidence level before applying pesticides?

Yes

No

At what level of pest attack do farmers begin to apply pesticides?

If the pests have attacked $1 / 16$ of plants grown

If the pests have attacked $1 / 8$ of plants grown

If the pests have attacked $1 / 4$ of plants grown

$17.5 \%$

If the pests have attacked $1 / 2$ of plants grown

What is your strategy to control the severe attack of pests and diseases?

Increase the dose/concentration of pesticides

Increase the interval of pesticide application

$40.5 \%$

Change the type of pesticides

Do you think that you did the right thing using chemical pesticides to control pests and diseases?

Yes

No

Do you prefer expensive pesticides or cheap ones?

Expensive

Cheap

Insecticides that farmers applied the most to control larvae of pests in

horticultural crops

Prevathon (Klorantraniliprol)

Curacron (Profenofos)

Dursban (Klorpirifos)

Sherpa (Sipermetrin)

Decis (Deltametrin)

Fungicides that farmers applied the most to control diseases in horticultural

crops

Dithane-45

Antracol

Daconil 


\subsection{The relation between age, educational background and farming experiences to the distribution and the application of pesticides by farmers}

Three sub-variables differentiated characteristics of respondents: age, educational background, and farming experience to evaluate its relationship with pesticide distribution and the use of pesticides by farmers (Table 5). The values of chi-square were obtained from the values of cross-tabulation to analyze variables tested. The analysis of age (sub variable) with knowledge (variable) of farmers illustrated that all variables tested did not show the correlation between them, and the analysis of the educational background and farming experience to the knowledge of farmers and the application of pesticides showed that only several variables which possessed significant result.

The distribution of pesticides had a strong correlation with educational background and farming experiences, which is expected that farmers aware of the importance of knowing pesticides, especially in applying chemical/synthetic pesticides. Knowledge is inseparable from educational background and professionalism in a particular field. Having higher education, which is suitable for the work they have, will enhance retailers' knowledge, and it will bring a positive impact to the pesticide distribution to the farmers, which resulted in the proper use of pesticides by farmers. Specific knowledge of someone will affect the way they think and act. More knowledge attributed to decisive action.

Positive actions bring a positive impact on the object, such as farmers. Ai Sukawati and Astri (2004) found that practice is a reaction to the stimulus which can be directly observed and it is related to knowledge and behavior. These three important components are inseparable even though sometimes these do not work together in its implementation. The research about these three components was in line with Anas et al. (2014). They evaluated that specific knowledge brings a positive impact on appropriate action. For example, if farmers knew about the impact of broad-spectrum pesticides, they would prefer narrow-spectrum pesticides, which will reduce the possibility of killing non-target organisms.

Table 5. The Mean Values of Correlation Between Retailers' Age, Educational Background, and Time Length of Business to The distribution of Pesticides and The Use of Pesticides by Farmers.

\begin{tabular}{|c|c|c|c|c|c|c|}
\hline \multirow{2}{*}{ Indicators } & \multicolumn{2}{|c|}{ Age } & \multicolumn{2}{|c|}{$\begin{array}{l}\text { Educational } \\
\text { background }\end{array}$} & \multicolumn{2}{|c|}{ Time length of business } \\
\hline & $\mathrm{X}^{2}$ & $\mathrm{X}^{2}(0.05)$ & $\mathrm{X}^{2}$ & $\mathrm{X}^{2}(0.05)$ & $\mathrm{X}^{2}$ & $\mathrm{X}^{2}(0.05)$ \\
\hline Types of pesticides distributed by retailers & 7.5 & 9.49 & 16.7 & 7.49 & 4.2 & 13.1 \\
\hline $\begin{array}{l}\text { Types of pesticide formulation approved by the } \\
\text { Ministry of Agriculture }\end{array}$ & 12.2 & 18.1 & 5.3 & 16.7 & 13 & 6.5 \\
\hline $\begin{array}{l}\text { Types of hazardous formulation of pesticides } \\
\text { classified by WHO }\end{array}$ & 9.5 & 11.1 & 8.5 & 7.7 & 1.25 & 7.5 \\
\hline Work codes of pesticides distributed & 2.5 & 10 & 0.12 & 5.8 & 8.8 & 11.1 \\
\hline
\end{tabular}

3.6 The correlation between age, educational background, and farming experience to the farmers' perception and behavior of using pesticides to control pests and diseases

The result has shown in Table 6. It revealed there were significant correlations between the behavior of farmers and all sub-variables: age, educational background and - farming experience at the probability level $5 \%(\alpha=0.05)$.

The analysis of the correlation between sub-variables and behavior of farmers in using pesticides demonstrated significant results at a probability level of $5 \%$. It means that age, educational background, and farming experience affect the behavior of farmers in applying pesticides to control pests and diseases. This confirmed that a better attitude of using pesticides is brought by the ability to master a specific field and also a productive age. 
Table 6. The Mean Values of Correlation Between Age, Educational Background, and Farming Experience and Farmers' Perception and Behavior in Using Pesticides to Control Pests and Diseases.

\begin{tabular}{|c|c|c|c|c|c|c|}
\hline \multirow{2}{*}{ Indicators } & \multicolumn{2}{|c|}{ Age } & \multicolumn{2}{|c|}{$\begin{array}{l}\text { Educational } \\
\text { background }\end{array}$} & \multicolumn{2}{|c|}{ Farming experience } \\
\hline & $\mathrm{X}^{2}$ & $\mathrm{X}^{2}(0.05)$ & $\mathrm{X}^{2}$ & $\mathrm{X}^{2}(0.05)$ & $\mathrm{X}^{2}$ & $\mathrm{X}^{2}(0.05)$ \\
\hline Frequency of pesticides application & 15.8 & 7.1 & 8 & 0.4 & 8 & 4.4 \\
\hline Application of mixed pesticides or non-mixed pesticides. & 11.11 & 1.05 & 10 & 1.31 & 4.0 & 2.5 \\
\hline Dose of pesticide used by farmers & 21 & 10.3 & 7 & 6.7 & 5.5 & 0.15 \\
\hline $\begin{array}{l}\text { Level of pest incidence triggered farmers to start applying } \\
\text { pesticides }\end{array}$ & 21.0 & 17.5 & 8 & 4.1 & 11.1 & 8.1 \\
\hline
\end{tabular}

\section{Conclusions}

The knowledge of retailers about the advantages, codes, and formulations of pesticides is still low. It has also occurred to farmers who have low knowledge of using pesticides, which can be estimated from the higher frequency and high dose of pesticide application. They often mix the pesticides with fungicides (sometimes more than 2 pesticides with 2 different pesticide codes and formulations) at one time.

The results of the Chi-square test showed that the age of retailers and farmers did not influence the distribution of pesticides significantly. However, educational background and selling experience do affect the pesticide distributions, which showed by the significant result on each indicator.

Farmers, which influenced by age, educational background, and farming experience, significantly affected farmers' perception and behavior in using pesticides to control pests and diseases. Knowledge, behavior, and attitude contributed to the application of pesticide and its exposure.

\section{REFERENCES}

Sukmawati, A., \& IP, A. M. (2004). Hubungan Antara Perilaku Dalam Pengelolaan Pestisida Dengan Aktivitas Enzim Cholinesterase Darah Pada Petani Cabe Di Desa Santana Mekar Kecamatan Cisayong Kabupaten Tasikmalaya. Jurnal Ekologi Kesehatan, 3(2 Agt).

Agne, S., Fleischer, G., Jungbluth, F. dan Waibel H. (1995). Guidelines for pesticides policy studies: a framework for analyzing economic and political factors of pesticides use in developing counteries. A Publication of the pesticide policy project. Series no 1. University of Hannover, Germany

Ameriana, M., Natwanidjaja, R. S., Arief, B., \& Karmana, M. H. (2006) Faktor-faktor yang Mempengaruhi Kepedulian Konsumen terhadap Sayuran Aman Residu Pestisida. Jurnal Hortikultura, 16(1).
Affandi, A., \& Sinaga, A. (2014). Hubungan Pengetahuan dan Persepsi Harga dengan Penggunaan Pestisida dalam Usahatani. Jurnal Agribisnis Indonesia, 2(2), 93-106.

Amilia, E., Joy, B., \& Sunardi, S. (2016). Residu Pestisida pada Tanaman Hortikultura (Studi Kasus di Desa Cihanjuang Rahayu Kecamatan Parongpong Kabupaten Bandung Barat). Agrikultura, 27(1).

Asih, D. N. (2009). Analisis karakteristik dan tingkat pendapatan usahatani bawang merah di Sulawesi Tengah. Agroland, 16(1).

Badan Pusat Statistik Karo. (2015). Karo Dalam Angka 2015. Katalog Badan Statsistik Kabupaten Karo

Badan Pusat Statistik Karo. (2016). Karo Dalam Angka 2016. Katabg Badan Statsistik Kabupaten Karo

Catur, Y.M.E., Budi. W., dan Henna. R. S. (2013). Tingkat pengetahuan petani dalam menggunakan pestisida (studi kasus didesa curut kecamatan penawangan kabupaten Grobongan) Prosiding Seminar Nasional Pengelolaan Sumber Daya Alam dan Lingkungan 2013.

Hidayat, F., Khamidi, T., \& Wiyono, S. (2010). Pengetahuan, Sikap dan Tindakan Petani Di Kabupaten Tegal dalam Penggunaan Pestisida dan Kaitannya dengan Tingkat Keracunan Terhadap Pestisida. Bumi Lestari Journal of Environment, 10(1).

Lilis. Z. (2015). Pengetahuan, sikap dan tindakan petani sayuran dalam penggunaan pestisida di kabupaten Pandeglang Banten (Script). Bogor. Departemen Proteksi Tanaman, Fakultas Pertanian, IPB, Bogor.

Maisura, M., Nurdin, M., \& Muslina, M. (2019). Effect of manure and NPK fertilizers on growth and production of onion (Allium cepa L.). Journal of Tropical Horticulture, 2(1), 16-18.

Sulistiyono, L., Tarumingkeng, R. C., Sanim, B., \& Dadang, D. (2002). Pengetahuan Sikap dan Tindakan Petani Bawang Merah dalam Penggunaan Pestisida (Studi Kasus di Kabupaten Nganjuk Propinsi Jawa Timur). Agroland, 15(1).

Ita. M.B. dan Syaad.A.S.(2013). Analisis potensi ekspor hal-hal pertanian di kabupaten Karo. J. Ekonomi dan Keuangan 1(5) :18-29

Nunung.K., Neti.T., Sri.H.S \& Adreng. P. (2011). Analisis efisiensi usahatani padi di beberapa sentra produksi padi di Indonesia. J. Agroekonomi 29(1):25-48.

Pham.V.H., Arthur. P.J.M., Peter.o., and Paul J.V.D.B. (2009). Pesticide distribution and use in vegetable production in the red river delta of Vietnam. J. Renewable agriculture and food system 24(3):174-185. 
Saut M.T., Dewi. H dan Novi. R. (2014). Pendapatan dan tingkat kesejahteraan petani lada dikecamatan gunung labuhan kabupaten way kanan. JII.A 2(3) :268-275.

Savitri, S., \& Usnawiyah, U. (2019). The potential of BASF NPK fertilizers associated with Trichoderma viride fertilizer on the growth and production of shallots (Allium ascalonicum L.). Journal of Tropical Horticulture, 2(1), 29-33.

Try. E., Tubagus.H., Suriaty. S. (2013). Perilaku petani dalam menggunakan pestisida kimia (kasus petani cabai di Pekon gisting atas kecamatan Gisting kabupaten Tanggamus. JIIA 1(4): 334-342.

Zulfita, D., Maulidi, M., \& Hariyanti, A. (2019). Application of Leaf Fertilizer Using Nano Technology To Read Vegetative Growth of Vanda sp. Journal of Tropical Horticulture, 2(1), 19-23. 